論文

$$
\begin{aligned}
& \text { ラマン分光法による塗布型防せい用のコンクリートへの浸透深さ評価 }{ }^{\dagger} \\
& \text { 齊藤 亮介* 高谷 哲** 鈴木 優人 } * * \text { 羽村 陽平 } * * * \text { 須藤 裕司 } * * * * \\
& \text { 星 博夫***** 若杉 三紀夫****** 山本 貴士** 宮川 豊章** }
\end{aligned}
$$

\title{
Evaluation of Penetration Depth of Penetrant Type Inhibitor into Concrete \\ by Raman Spectroscopy
}

\author{
by

\begin{abstract}
Ryosuke SaIto*, Satoshi Takaya**, Yuto Suzuki**, Yohei Hamura***, Yuhji Sudoh****,
\end{abstract} \\ Hiroo Hoshi*****, Mikio Wakasugi ${ }^{* * * * * *}$, Takashi Yamamoto** and Toyoaki MiyagaWa $* *$
}

\begin{abstract}
Corrosion of reinforcement is the representative deterioration of concrete structures, and it may cause the reduction in load-carrying capacity. Therefore, protecting reinforcement from corrosion is one of important subjects for concrete structures. Recently, in order to protect reinforcement, use of penetrant type inhibitor is increasing. However, evaluation method of penetration depth of these materials has not been established, and it is difficult to judge whether these materials work well or not.

Then in this study, in order to develop the technique to evaluate penetration depth by surface analysis in the future, evaluation of penetration depth and active ingredient amount of 3 penetrant type inhibitors were tried by Raman spectroscopy as a basic study. To evaluate the amount, granular silica was mixed into concrete as a target of Raman spectroscopy analysis, and the amount penetrated into the silica ball was analyzed. Here we found that as the depth from coated surface became deeper, the relative amount of the detected active ingredient becomes smaller. This result indicates that the penetration depth can be predicted by evaluating the near surface by Raman spectroscopy.
\end{abstract}

\section{Key words:}

Corrosion, Penetrant, Inhibitor, Penetration depth, Raman spectroscopy

\section{1 緒 言}

コンクリート中の細孔は $\mathrm{pH} 12 \sim 13$ の $\mathrm{Ca}(\mathrm{OH})_{2}$ 水溶液 で満たされているため, コンクリート中の鉄筋は不動態 化しており腐食しにくいことはよく知られている。しか し，実構造物において塩化物イオンの侵入や中性化によ るコンクリート中細孔の $\mathrm{pH}$ 低下による鉄筋腐食の事例 が数多く報告されている．コンクリート中の鉄筋が腐食 すると，腐食生成物の体積が元の鉄筋体積よりも大きい ため，かぶりコンクリートにひび割れが生じる，腐食が 進行すると，鉄筋径の減少や，鉄筋とコンクリートの付 着力の低下，かぶりのひび割れなどによるじん性や構造 耐荷力の低下につながる危険性があるため，鉄筋腐食の 抑制はコンクリート構造物の抱える重要な課題のひと つとなっている。近年では，腐食を抑制するために塗布 型の防せい剤を使用することも増えてきているが，これ らの材料の浸透深さを現地で評価する手法は確立され
ておらず，十分な効果が得られているかを判断できない のが現状である.

現地で浸透深さを評価するには，塗布表面から何等か の指標により非破壊で浸透深さを推定することが理想 的である. 本研究では, 将来的にコンクリート表面の分 析を行うことで浸透深さを推定する技術としてラマン 分光法を用いた手法に着目した. ラマン分光法は, 特に 表面情報の取得に有用な分析手法であり, 測定対象が有 する化学結合や含有された化合物の同定が可能で, 分析 によって得られるスペクトルの強度からは相対的な含 有量の算出も可能である. さらに，ラマン分光装置は性 能を限定すれば小型化が可能であり現場での活用が期 待できることがわかっている ${ }^{1)}$.

ラマン分光法による評価技術を開発するための基礎 研究として, 塗布型防せい剤のラマン分光特性を把握し た.さらに，コンクリート表面に塗布した防せい剤の浸

原稿受理 平成29年 1月10日 Received Jan. 10, $2017 @ 2017$ The Society of Materials Science, Japan

正 会 員 清水建設(株) 技術研究所 $\bar{\top} 135-8530$ 東京都江東区越中島

Shimizu Co., Ltd., Etchujima, Koto-ku, Tokyo 135-8530.

** 正 会 員 京都大学大学院工学研究科 社会基盤工学専攻 $7615-8540$ 京都市西京区京都大学桂

Dept. of Civil and Earth Resources Eng., Kyoto Univ., Nishikyo-ku, Kyoto 615-8540.

*** 正 会 員 (株)島津テクノリサーチ 試験解析事業部 † 604-8436 京都市中京区西/京下合町

Shimadzu Techno-Research, Inc., Testing and Analysis Div., Nakagyo-ku, Kyoto 604-8436.

正 会 員 日産化学工業(株) 化学品事業部基礎化学品営業部 $\overline{1} 101-0054$ 東京都千代田区神田錦町

Nissan Chemical Industries, Ltd., Chemicals Div., Basic Chemicals Dep., Chiyoda-ku, Tokyo 101-0054.

***** BASFジャパン(株) 建設化学品事業部 テ106-6121 東京都港区六本木

BASF Japan, Ltd, Construction Chemicails Div., Minato-ku, Tokyo 106-6121.

****** 正 会 員 (株) ケミカル工事 事業統括本部 广658-0024 神戸市東灘区魚崎浜町

Chemical Koji, Co., Ltd., Business Headquater, Higashinada-ku, Kobe 658-0024. 
透深さや有効成分量についてラマン分光法により評価 できるかを検討した。

\section{2 塗布型防せい剂のラマン分光特性}

\section{$2 \cdot 1$ 目的}

ラマン分光法を用いて塗布型防せい剤のコンクリート への浸透特性評価を行うに当たり，各塗布型防せい剤の ラマン分光特性を把握することを目的に，各塗布型防せ い剤の原液および原液を含浸させた粒状シリカに対して ラマン分光分析を実施した.

\section{$2 \cdot 2$ 実験概要}

本研究で使用したのは市販されている次の材料である. 1）防せい剤 A（亜硝酸リチウム $40 \%$ 水溶液）

塩化物イオンに対して十分な量の亜硝酸イオンがある と腐食抑制効果があることが知られている ${ }^{2)}$. 一般的には 酸化剂として作用するアノード型インヒビターとされて いるが 3)，コンクリート中の鉄筋に作用した場合には，亜 硝酸イオンが吸着して塩化物イオンなどの競合イオンの 作用を妨げる可能性があることも報告されている ${ }^{4)}$.

2）防せい剤 B（シラン系鉄筋腐食抑制剤）

シランは，加水分解反応を起こすことでシラノールに 変化し，部分的に縮合重合反応を起こしてオリゴマーに なる．このオリゴマーが脱水縮合することでコンクリー 卜中に撥水層を形成することができる。この撥水層によ る腐食抑制効果も期待できるが，防せい剤 B は高含浸夕 イプであるため，コンクリート中の鉄筋位置まで浸透す ると, $\mathrm{Fe}_{3} \mathrm{O}_{4}$ を再生させ安定化させることで腐食抑制効果 を発揮すると報告されている5).

3）防せい剤 C（アミノカルボン酸系含浸材）

シラン系撥水剂と浸透移行型気化性防せい剂が配合さ れたものであり，防せい成分がコンクリート中の鉄筋ま で浸透すると，鉄筋表面に吸着することにより保護層を 形成する。この保護層の親和力が水や塩化物イオンより も強いため腐食抑制効果を発揮する.

これら 3 材料の寸べてについて, 原液数 $\mathrm{mL}$ をガラス製 容器に汲み取り分析を行った。その他，粒状シリカによ る分析を防せい凰 $\mathrm{B}$ および $\mathrm{C}$ に対して実施した。これら はコンクリートへの浸透過程でシランの加水分解と脱水 縮合を生じ，時間の経過とともにラマンスペクトルが変 化する可能性が考えられたためである。 コンクリート中 のアルカリ環境を想定し， $0.1 \mathrm{M}$ 水酸化ナトリウム溶液を 吸水させた直径 $2 \mathrm{~mm}$ 程度の粒状シリカに防せい剤 $\mathrm{B}$ およ び C をそれぞれ含浸させ， 3 時間後，14 日後に粒状シリ カを割裂し，割裂面に対してラマン分光分析を実施した. 使用した粒状シリカの外観を Fig. 1 に示す.

本研究では，使用した分析装置にて利用可能な波長 $532 \mathrm{~nm}, 633 \mathrm{~nm}, 785 \mathrm{~nm}$ の 3 種類のレーザーの内，最も検 出精度の高い波長 $532 \mathrm{~nm}$ のレーザーを入射光として分析 を実施した。ただし，防せい剤 B の分析時には蛍光によ るバックグラウンドの上昇が確認されたため, 波長 $785 \mathrm{~nm}$ のレーザーも使用した。

\section{$2 \cdot 3$ 分析結果}

防せい凨 A の分析結果を Fig. 2 に, 防せい剤 B の分析結 果を Fig. 3 に，防せい凰 C の分析結果を Fig. 4 に示す. そ れぞれの材料について，次章のコンクリート供試体での検 討時に着目すべきピークを次に示す.

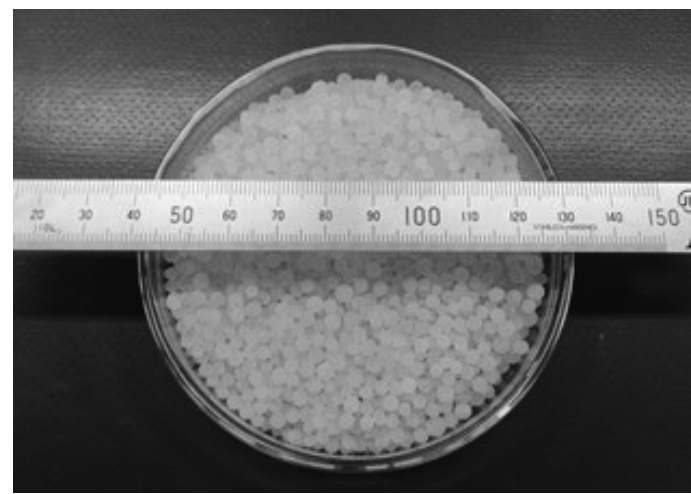

Fig. 1 Silica ball.

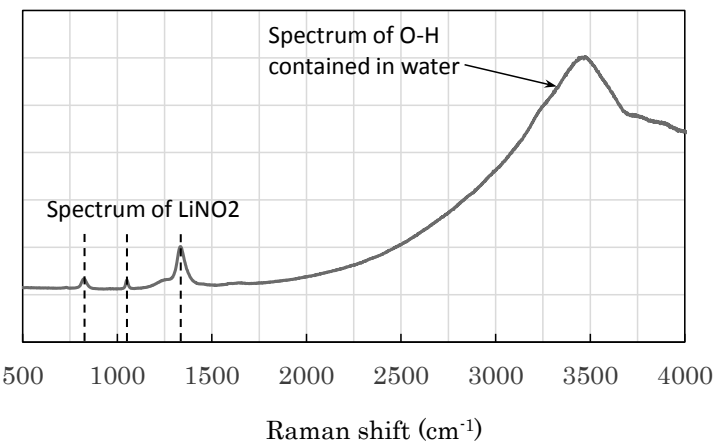

Fig. 2 Raman spectrum of Inhibitor A.

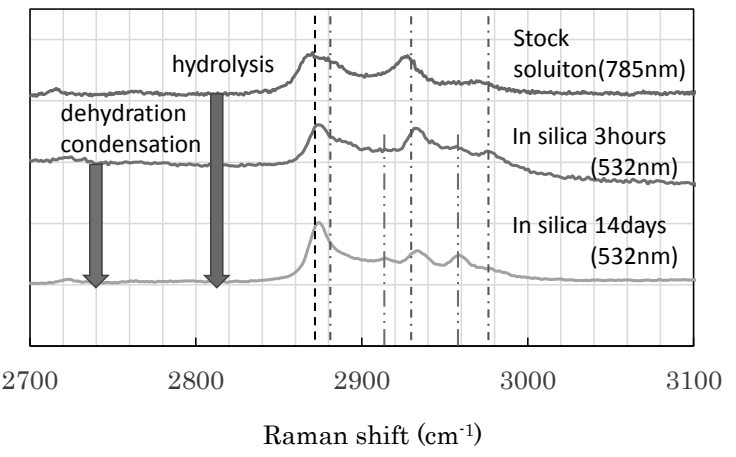

Fig. 3 Raman spectrum of Inhibitor B.

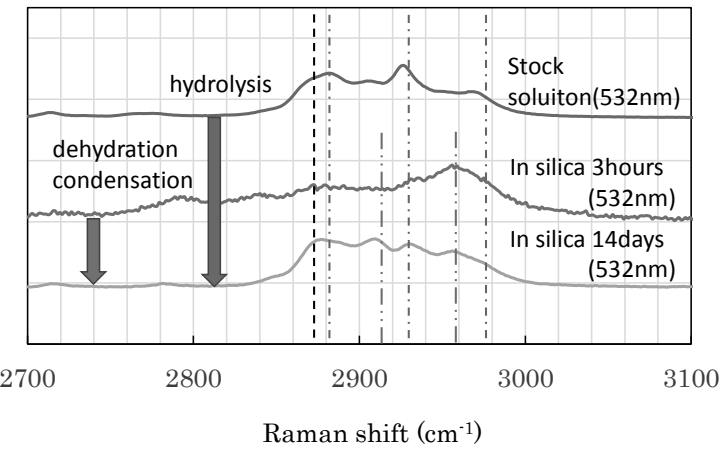

Fig. 4 Raman spectrum of Inhibitor C. 
Table 1 Mix proportion and measured values of slump and air content.

\begin{tabular}{|c|c|c|c|c|c|c|c|c|}
\hline & $\mathrm{W}(\mathrm{kg})$ & $\mathrm{C}(\mathrm{kg})$ & $\mathrm{S}(\mathrm{kg})$ & $\mathrm{G}(\mathrm{kg})$ & $\mathrm{Si}(\mathrm{kg})$ & Slump $(\mathrm{cm})$ & Air $(\%)$ \\
\hline \multirow{3}{*}{ W/C } & 40 & 165 & 411 & 726 & 1010 & 60 & 16.0 & 4.5 \\
\cline { 2 - 9 } & 50 & 165 & 330 & 808 & 995 & 60 & 17.0 & 4.5 \\
\cline { 2 - 9 } & 60 & 165 & 275 & 884 & 965 & 60 & 17.0 & 4.3 \\
\hline
\end{tabular}

1)防せい剤 $\mathrm{A}$

Fig. 2 から，防せい剤 A では 800，1000，1400 $\mathrm{cm}^{-1}$ 付近 に特徽的なピーク（破線）が現れることがわかる. 800 お よび $1000 \mathrm{~cm}^{-1}$ は炭酸カルシウムのピークと近く ${ }^{6)}$, コンク リート中では炭酸カルシウムとの区別が難しいことから， $1400 \mathrm{~cm}^{-1}$ 付近のピークに着目する.

2) 防せい鼡B

Fig. 3 から, 原液で確認された 2880,2930 および2980c m 付近のピーク (一点鎖線) が，シリカに含浸させた 3 時間 後および 14 日後には相対的に減少あるいは消失している ことがわかる．これは，反応過程でシランの有する加水分 解性基が減少することに起因すると考えられる. 一方で, $2920 \mathrm{~cm}^{-1}, 2960 \mathrm{~cm}^{-1}$ 付近のピーク (二点鎖線) が新たに出 現している.このうち， $2960 \mathrm{~cm}^{-1}$ 付近のピークはシリカに 含浸させた 3 時間後には確認されるものの, $2920 \mathrm{~cm}^{-1}$ 付近 のピークは 3 時間後には確認できないことがわかる．この ことから，2960 $\mathrm{cm}^{-1}$ 付近のピークは加水分解によって形成 されるシラノール結合 $(\mathrm{Si}-\mathrm{OH})$ に起因し, $2920 \mathrm{~cm}^{-1}$ 付近のピ 一クは脱水縮合により形成される Si-O-の結合に起因する と考えられる。

$2880 \sim 2870 \mathrm{~cm}^{-1}$ のピーク (破線) は変化がないことから， 加水分解反応に関与しないと考えられ, 防せい凨 B は 2880 〜2870 $\mathrm{cm}^{-1}$ のピークに着目する.

3) 防せい剤C

Fig. 4 から，防せい剤 B と同様に，2880，2930 および $2980 \mathrm{~cm}^{-1}$ 付近のピークが相対的に減少あるいは消失し, 2920 および $2960 \mathrm{~cm}^{-1}$ 付近のピークが新たに出現したこと が確認できる．これは，防せい剤 C に含まれるシラン系撥 水剤によるものと判断できる. しかし，シラノール結合 $(\mathrm{Si}-\mathrm{OH})$ と見られる $2960 \mathrm{~cm}^{-1}$ のピークが, シリカに含浸させ た 3 時間後には相対的に大きくなり，2 週間後には相対的 に小さくなっている。このことから，防せい剤 B よりも初 期の加水分解反応の速度が大きいと考えられ，加水分解性 官能基が防せい剤 B に含まれるものとは異なると推察さ れる.

防せい剤Cについても 2880〜2870 $\mathrm{cm}^{-1}$ のピークは反応に 関与しないことから，防せい剤 $\mathrm{B}$ と同様にシラン系撥水剤 に起因する 2880〜2870 $\mathrm{cm}^{-1}$ のピークに着目する.

\section{3 ラマン分光法による塗布型防せい剂の浸透特性評価}

\section{$3 \cdot 1$ 目的}

コンクリート供試体の表面に各種防せい剤を塗布し，浸 透深さや有効成分量の違いをラマン分光法により評価でき るかを検討した，その際，ラマンスペクトルにおいてピー ク強度が大きいほど，そのピークに対応する物質の含有量

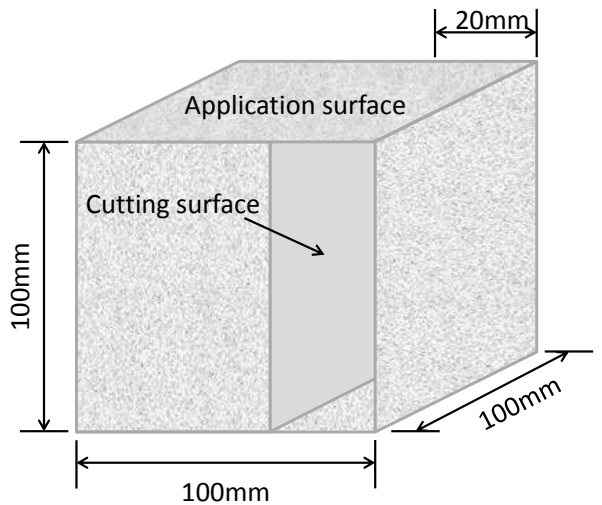

Fig. 5 Specimen.

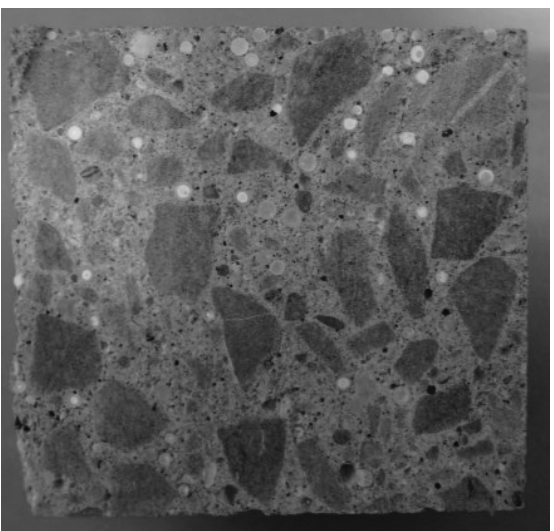

Fig. 6 Cutting surface of the specimen.

Table 2 Results of permeability coefficient and moisture content measurement.

\begin{tabular}{|c|c|c|c|}
\hline \multirow{3}{*}{ W/C } & $\begin{array}{c}\mathrm{kt} \\
\left(\mathrm{x} 10^{-16} \mathrm{~m}^{2}\right)\end{array}$ & $\begin{array}{c}\text { Moisture } \\
\text { Content (\%) }\end{array}$ \\
\hline \multirow{4}{*}{40} & 1 & 0.0042 & 5.0 \\
\cline { 2 - 4 } & 2 & 0.0073 & 5.2 \\
\cline { 2 - 4 } & Average & 0.0054 & 5.1 \\
\hline \multirow{4}{*}{50} & 1 & 0.0069 & 5.1 \\
\cline { 2 - 4 } & 2 & 0.0090 & 4.8 \\
\cline { 2 - 4 } & 3 & 0.0069 & 5.0 \\
\cline { 2 - 4 } & Average & 0.0076 & 4.8 \\
\hline \multirow{5}{*}{60} & 1 & 0.014 & 5.1 \\
\cline { 2 - 4 } & 2 & 0.039 & 4.8 \\
\cline { 2 - 4 } & 3 & 0.027 & 4.8 \\
\cline { 2 - 4 } & Average & 0.027 & 4.9 \\
\hline
\end{tabular}

が多い特性を利用した．ただし，ピーク強度から有効成分 の絶対量を算出することはできないため, 分析のターゲッ トとして粒状シリカを供試体に混入し, シリカのピーク強 度との相対比較によって浸透した防せい剤の有効成分量を 評価した．評価方法の詳細は後述する. 


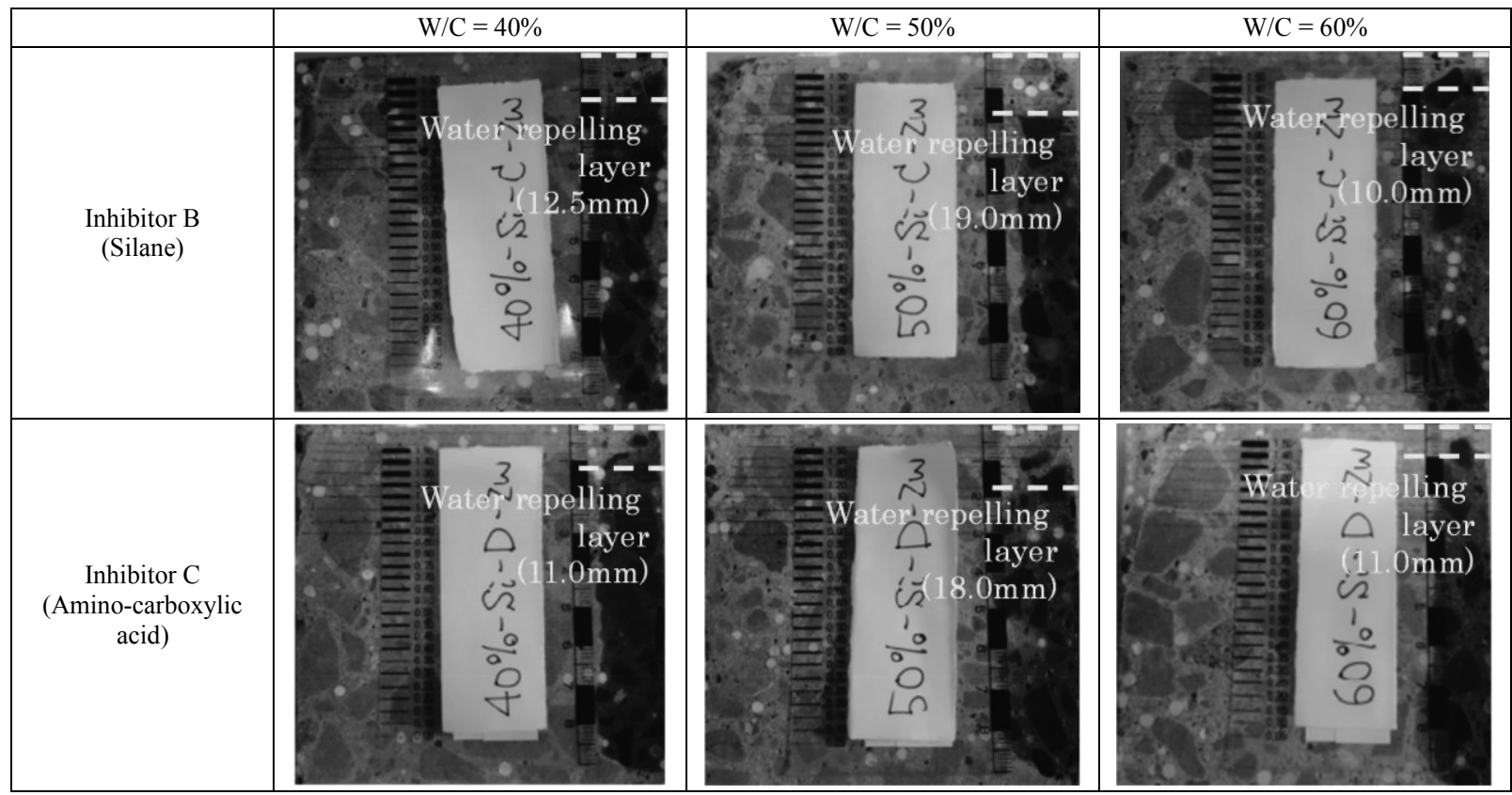

Fig. 7 Observation results of water repelling depth.

\section{$3 \cdot 2$ 実験概要}

供試体は Fig. 5 に示寸 $100 \times 100 \times 100 \mathrm{~mm}$ のコンクリート とし，W/C は 40，50，60\%の 3 種類とした。塗布する防せ い㶡は第2 章で使用したものと同じ 3 種類を用いた.また, ラマン分光法により得られるスペクトルにより相対量の比 較を行うために, Fig. 1 に示した粒状シリカを表乾状態に し, $60 \mathrm{~kg} / \mathrm{m}^{3}$ 混入した. 配合表, スランプ, 空気量の測定 結果を Table 1 に示す.

試験の手順は以下の通りである.

1) 供試体を打設後，2週間水中養生を行い，その後2週間 の気中養生 $\left(20^{\circ} \mathrm{C} \pm 2{ }^{\circ} \mathrm{C}, 60 \pm 5 \% \mathrm{RH}\right)$ を行った.

2) W/Cによる物質透過性の違いを評価するために透気係 数の測定を行った.

3）含水率を測定し, 含水率が概小 $5 \%$ 程度になっているこ とを確認した後，防せい剤の塗布を行った．塗布は打 設時の側面とし，塗布量は，防せい剤Aは $200 \mathrm{~g} / \mathrm{m}^{2}$, 防 せい剤Bは600 $\mathrm{g} / \mathrm{m}^{2}$, 防せい剤 $\mathrm{C} は 300 \mathrm{~g} / \mathrm{m}^{2}$ とした。

4) 塗布後 2 週間気中養生 $\left(20^{\circ} \mathrm{C} \pm 2{ }^{\circ} \mathrm{C}, 60 \pm 5 \% \mathrm{RH}\right)$ を行 った後に, Fig. 5に示す面で切断し, Fig. 6のように切 断面に配置された粒状シリカの断面の中央を塗布面 から $3 \mathrm{~mm}$ 間隔でラマン分光法により分析した. また, 浸透している領域で撥水層を形成すると考えられた 防せい剤BおよびCについては切断面の一部を十数秒 間水に浸せきし，濡れ色が確認できない層を撥水層と して，その形成深さの確認も行った.

\section{$3 \cdot 3$ 実験結果および考察}

透気係数および表面水分率の測定結果をTable 2 に示す. 表を見ると，透気係数(kt值)はW/C $=40 \%<50 \%<60 \%$ の順 に大きくなっており，W/Cを変えたことにより供試体の物 質透過性に違いが生じたことが確認された. しかし, 最も

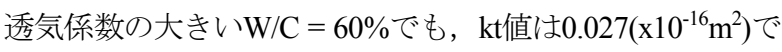
あり, 一般的に用いられている透気係数の指標では優〜良

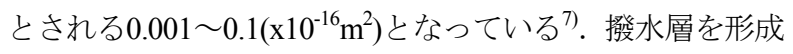
している範囲を確認した結果をFig. 7に示す. 図を見ると， 防せい剤 $\mathrm{B}$ ，防せい剤CともにW/C $=50 \%$ が最も深くまで 撥水層を形成しており，W/C $=40 \%$ と $60 \%$ の間には大きな 違いは見られないことが分かる. この理由については後述 する.

各防せい剤において, 塗布面から梁さ方向に分析して得 られたスペクトルをW/C $=40 \%$ を例にとってFig. 8に示す. 深い位置での分析結果は, 注目したピーク強度が小さいた め, 拡大図も掲載している. 図を見ると, 防せい剤Aは6〜 9mmの深さまで確認できたが, 9〜12mmではピークは得ら れなかった。一方, 防せい風Bや防せい剤Cでは, 強度は小 さいが12〜 15mmの深さまでシランに起因するピークを確 認することができた．これは，概ね撥水層を形成している 深さと一致する結果となっており, 撥水層を形成するため に必要な有効成分量が浸透していればラマン分光分析によ り検出可能であると考えられる.

次に, ターゲットとなるシリカ $(\mathrm{Si})$ と塗布型防せい剤(In) のスペクトル強度比 $(\mathrm{In} / \mathrm{Si})$ を用いて, 深さ方向の相対的な 有効成分量の分布を求めた. シリカは既報包参考に $488 \mathrm{~cm}^{-1}$ とし, 各防せい凨は第2章に示したとおり, 防せい 剂 $\mathrm{A} は 1400 \mathrm{~cm}^{-1}$, 防せい剂B $\mathrm{B}$ 防せい剂Cは2880〜 2870 $\mathrm{cm}^{-1}$ のピークをそれぞれ用いた. バックグラウンドが平坦では ない結果も多かったことから, Fig. 9に示寸ようにバンド幅 を $200 \mathrm{~cm}^{-1} と し$, バックグラウンドの平均值との差をピーク 強度とした. 例えば, $488 \mathrm{~cm}^{-1}$ のシリカの強度 $(\mathrm{Si})$ は, $488 \mathrm{~cm}^{-1}$ におけるピーク強度から $388 \mathrm{~cm}^{-1}$ の強度と $588 \mathrm{~cm}^{-1}$ の強度の 平均值を差し引いた值となっている. 得られた $\mathrm{In} / \mathrm{Si}$ の分布 をFig. 10に示す. 縦軸が $\mathrm{In} / \mathrm{Si}$ 比, 横軸が塗布面からの深さ となっており, 例えば 0 〜 $3 \mathrm{~mm}$ の区間の測定值は深さ $1.5 \mathrm{~mm}$ としてプロットしている. また，防せい剤BおよびCでは狳 布面付近のIn/ $\mathrm{Si}$ の值が大きいため, 縦軸を $(\mathrm{In} / \mathrm{Si})^{1 / 2}$ とした. 

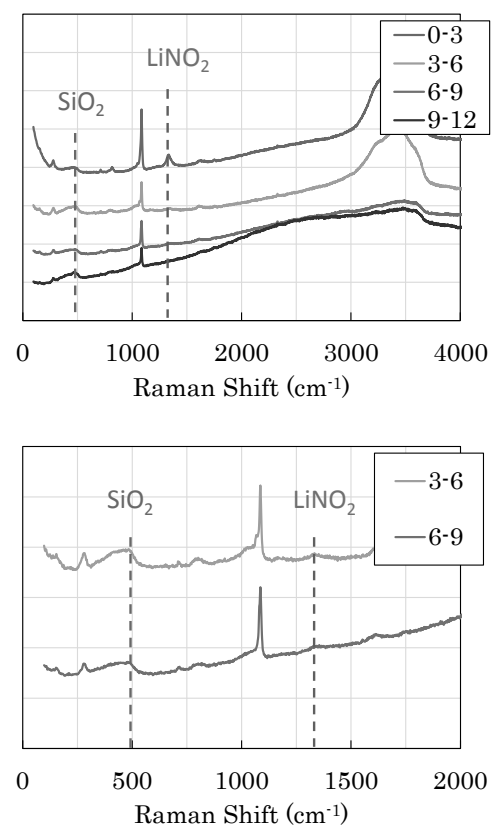

(a) Inhibitor $\mathrm{A}\left(\mathrm{LiNO}_{2}\right)$

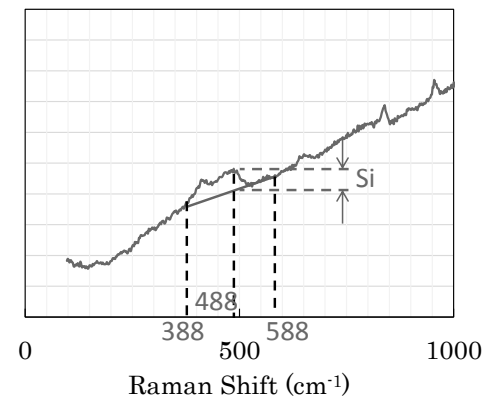

(a) $\mathrm{SiO}_{2}$
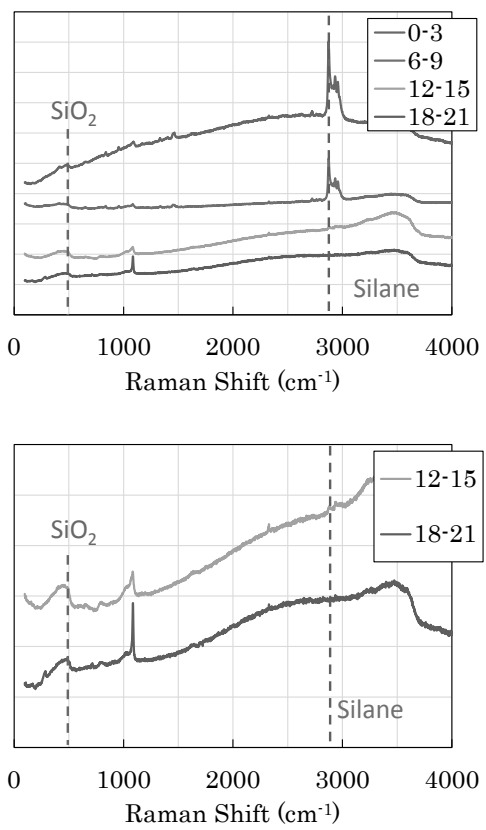

(b) Inhibitor B (Silane)

Fig. 8 Obtained spectrum of each depth $(\mathrm{W} / \mathrm{C}=40 \%)$. (b) Inhibitor $\mathrm{A}\left(\mathrm{LiNO}_{2}\right)$
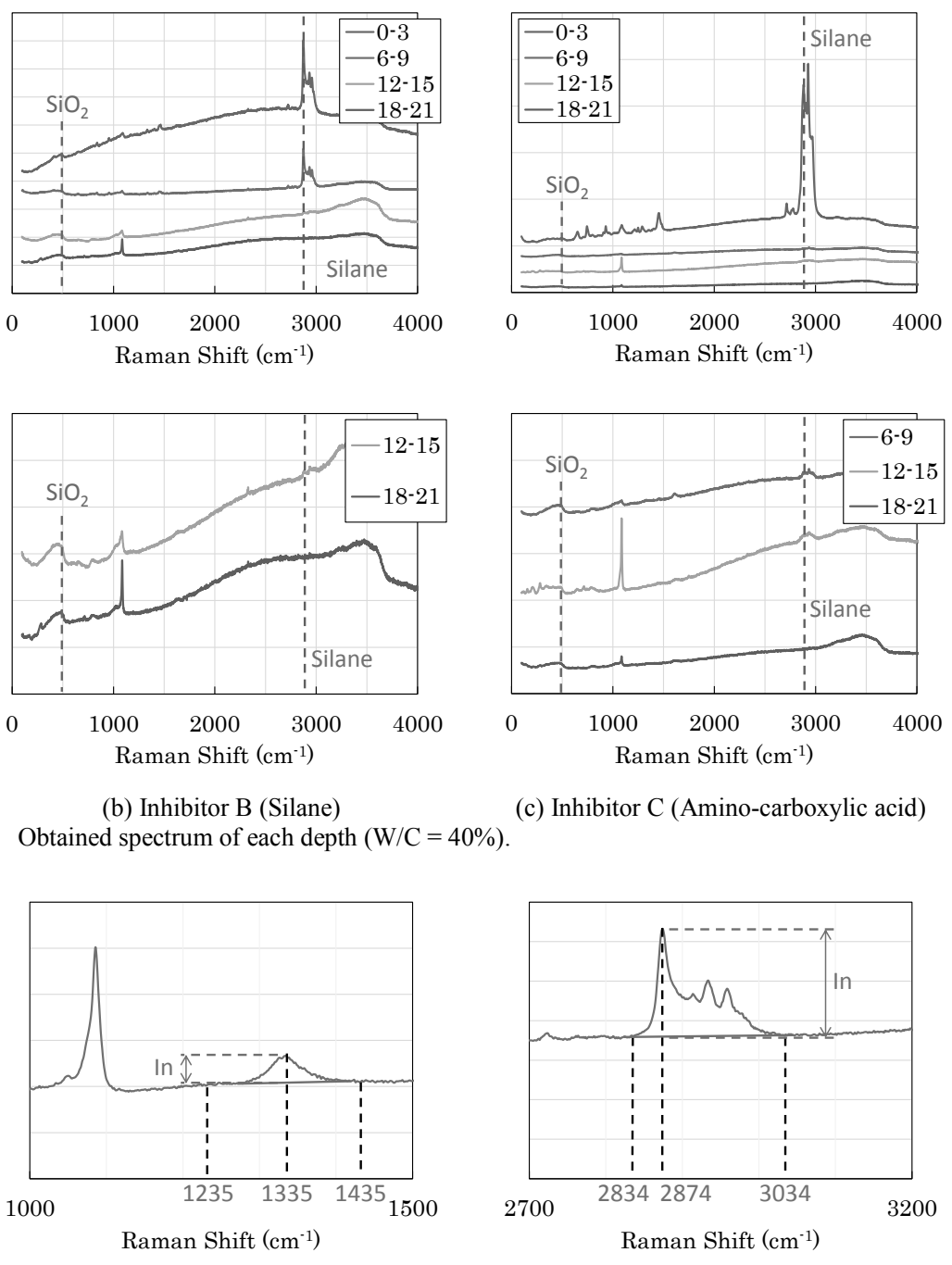

(c) Inhibitor C (Amino-carboxylic acid)

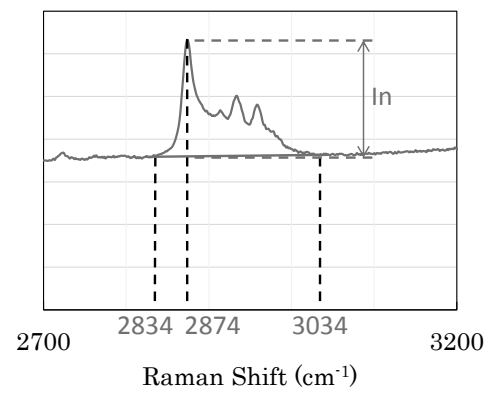

(c) Inhibitor B (Silane) and Inhibitor C (Amino-carboxylic acid)

Fig. 9 Calculation method of peak intensity.

Fig. 10から，いずれの防せい剤についてもW/Cによる傾 向の違いが明確に表れていないが，全体的な傾向として， 塗布面からの深さが深くなるほどIn/Siあるいは $(\mathrm{In} / \mathrm{Si})^{1 / 2}$ の 值が段階的に小さくなっていることが確認できる．これに より，塗布面近傍を評価することで内部の浸透深さを予測 できる可能性が示された．また，Fig. 7 とFig. 10から，防せ い剤Bでは $(\mathrm{In} / \mathrm{Si})^{1 / 2}=0.5$ 程度，防せい鼡Cでは $(\mathrm{In} / \mathrm{Si})^{1 / 2}=0.5$ 〜1.0程度であれば, 撥水層が形成されるものと推察される.

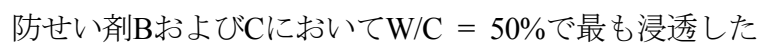
理由は以下のように考えられる.

1) $\mathrm{W} / \mathrm{C}=40 \%$ では, $\mathrm{W} / \mathrm{C}=50 \%$ おび $60 \%$ よりも細孔構造 が緻密であり，物質移動抵抗性が高かったと考えられ る．また，シランの硬化反応はアルカリ環境下におい ては加水分解反応が律速になることが知られており ${ }^{8)}$, 他2水準に比べて気中養生時にコンクリート内部の水 が抜けにくく，シランの加水分解反応が生じやすくな ったために硬化反応が早期に生じ，浸透を阻害した可 能性もある。

2) $\mathrm{W} / \mathrm{C}=50 \%$ では，40\%に比べて細孔構造が粗であるこ とが予想され，これに伴い気中養生時に $40 \%$ に比べて
深いところまで水が抜けたと考えられる. そのために より深いところまで未反応の状態で浸透し, 撥水層を 形成したと考えられる.

3） $\mathrm{W} / \mathrm{C}=60 \%$ では，50\%よりもさらに細孔構造が粗にな り, 気中養生時にコンクリート内部の水分は抜けやす くなったと考えられるが，防せい剤が比較的粗大な空 隙内に溜まりやすくなり，深くまで浸透できなかった と推察される.

本研究では，それぞれのコンクリート供試体の細孔構造 の分析は実施していないが，コンクリート中への物質移動 は細孔構造の影響が支配的であると考えられ9)，浸透深さ と細孔構造には何等かの関係があると推察される.また, 本研究で用いた供試体の透気係数は，0.001〜0.1( $\left(\mathrm{x}^{-16} \mathrm{~m}^{2}\right)$ と非常に小さく, 塗布型防せい剤の使用が期待されるコン クリートとは物質透過性状が異なる可能性があると考えら れる. 今後は透気係数が良〜一般となる $0.1 \sim 1.0\left(\times 10^{-16} \mathrm{~m}^{2}\right)$ 程度のコンクリートについて, 細孔構造も含めた検討が必 要である.

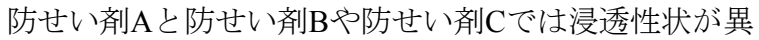
なる結果となっているが，硬化反応を生じる防せい剤Bお 


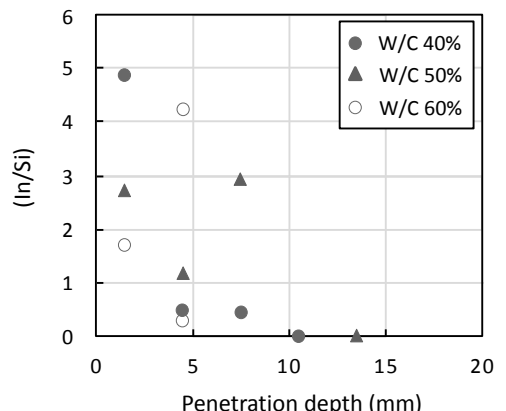

(a) Inhibitor $\mathrm{A}\left(\mathrm{LiNO}_{2}\right)$

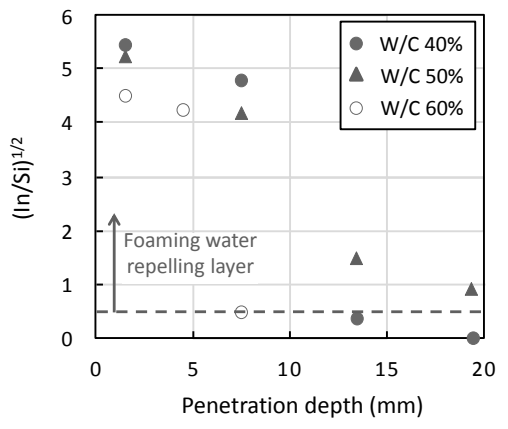

(b) Inhibitor B (Silane)

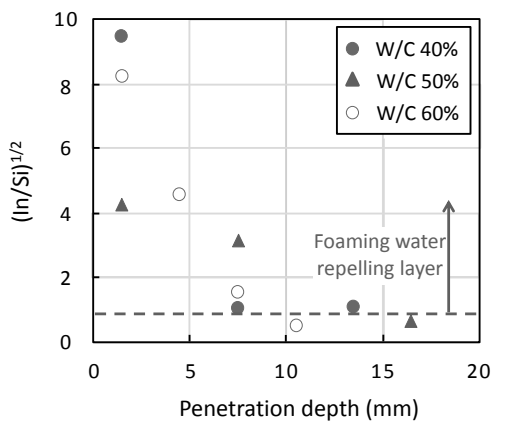

(c) Inhibitor C (Amino-carboxylic acid)

Fig. 10 Concentration distribution of each penetrant.

よびCの方が深くまで浸透したメカニズムについては，現 段階では明確な理由は不明である。さらに，本研究では実 際に腐食抑制に必要な有効成分量は議論できていないため, この点についても今後検討が必要である．また，実構造物 ではターゲットのシリカが埋設されていないため，実構造 物において評価する際の手法についても今後検討が必要で ある。

\section{4 結 言}

本研究では, 将来的にラマン分光法により塗布型防せ い剤の浸透深さを推定するための基礎的な検討として, 防せい剂 $\mathrm{A}$ (亜硝酸リチウ $40 \%$ 水溶液), 防せい剤B（シ ラン系鉄筀腐食抑制剤)，防せい剤C（アミノカルボン酸 系含浸材）のラマン分光特性の評価を行い, さらにコン クリートに塗布した各防せい剤の浸透深さの評価を行 った。その結果得られた主な結論を以下に示す.

（1）各塗布型防せい剤のラマンスペクトルを評価した 結果, 防せい剤BおよびCではシランの加水分解と脱 水縮合により，ラマンスペクトルが経時変化するこ とがわかった。コンクリート中での評価については,

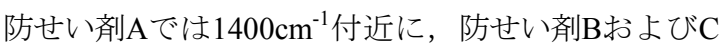
は2880〜2870 $\mathrm{cm}^{-1}$ 付近に現れるピークに着目すれば よいことがわかった。

（2）コンクリート供試体に塗布して，切断面の分析を行 った結果，防せい剤BおよびCは撥水層を形成された 深さと，ラマン分光法により有効成分を検出できた 深さが一致した.

（3）浸透した有効成分量を塗布型防せい剤のピーク強 度 $(\mathrm{In})$ とシリカの強度 $(\mathrm{Si})$ の比である $\mathrm{In} / \mathrm{Si}$ 比で評価 した結果，塗布面からの深さが深くなるほどIn/Siある いは $(\mathrm{In} / \mathrm{Si})^{1 / 2}$ の值が段階的に小さくなっていることが 確認され, 今後表面近傍の分析により浸透深さを評 価できる可能性が示された.
1) K. Kawakami, S. Takaya, Y. Hamura and T. Yamamoto "Evaluation of corrosion environment of reinforcement in concrete based on analysis of corrosion products", Proceedings of the Japan Concrete Institute, Vol.38, No.1, pp.1107-1112 (2016).

2) Y. Hama, O. Senbu and R. Akita, "Influence of nitrite ion and chloride ion on reinforcement corrosion in concrete", Proceedings of the Japan Concrete Institute, Vol.22, No.2, pp.55-60 (2000).

3) K. Aramaki, "Action of corrosion inhibitors (Part 2)", Zairyo-to-Kankyo, Vol.56, No.7, pp.292-300 (2007).

4) S. Takaya, Y. Sudoh, T. Naito, K. Era, T. Yamamoto and T. Miyagawa, "Basic study on corrosion controlling mechanism of nitrite ion and its effectiveness in concrete", Journal of the Society of Materials Science, Japan, Vol.63, No.10, pp.722-728 (2014).

5) T. Kanemitsu, S. Takaya, K. Fukawa and T. Yamamoto, "Corrosion controlling effect and mechanism of high penetration type silane penetrant", Proceedings of the Japan Concrete Institute, Vol.37, pp.913-918 (2015).

6) Y. Hamura, S. Takaya, N. Ueda, Y. Hiroi and T. Yamamoto, "Basic study on raman spectral property of ASR reactive aggregate and products", Journal of the Society of Materials Science, Japan,Vol.65, No.11, pp.793-799 (2016).

7) Torrent, R. and Frenzer, G.: A method for the rapid determination of the coefficient of permeability of the "covercrete", International Symposium Non-Destructive Testing in Civil Engineering (NDT-CE), pp.985-992, Sept.1995.

8) Dow Corning Toray Co. Ltd., "A guide to silane solutions" (2008).

9) Y. Sakai, C. Nakamura and T. Kishi, "Extraction and verification of the indicator of pore structure, which governs mass transfer resistance in concrete", Journal of Japan society of Civil Engineering E2, Vol.70, No.4, pp.390-401 (2014). 